\title{
Accumulation versus remobilization of mercury in sediments of a contaminated lagoon
}

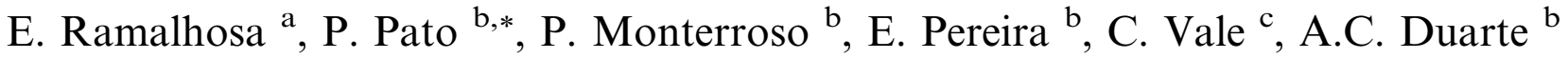 \\ ${ }^{a}$ Escola Superior Agrária de Bragança, CIMO, Campus de Santa Apolónia, 5301-855 Bragança, Portugal \\ ${ }^{\mathrm{b}}$ Department of Chemistry, University of Aveiro, Campus de Santiago, 3810-193 Aveiro, Portugal \\ ${ }^{\mathrm{c}}$ National Institute of Agronomy and Fishery Research, Av. de Brasília, 1400-196 Lisboa, Portugal
}

Once discharged in aquatic systems, mercury has a high affinity with suspended particles which contributes to its removal from water and to sink in nearby sediments (Wallmann et al., 1996; Lee et al., 1998). Thus, mercury concentrations in sediments are generally higher and therefore this compartment is considered a sink of mercury and simultaneously a potential source to interstitial waters and to biota, mostly to the organisms that live in contact with the sediments (Arakel, 1995; May et al., 1997). The accumulation of mercury in aquatic organisms has been subject of many studies (Becher and Bigham, 1995; Chapman, 1997; Lawson and Mason, 1998) and it has been observed that the incorporation of $\mathrm{Hg}$ in fish depends on metabolic factors and metal bioavailability (Driscoll et al., 1995).

Ria de Aveiro, a coastal lagoon in the Portuguese western coast, has for the last four decades, been subject to the discharge of several industrial and domestic effluents (Hall, 1982). A chemical complex located in Estarreja produced fertilisers, mineral acids, chlorine and soda, plastics, aromatics and other products. Its effluents have been, at least in part, rejected in a branch of the lagoon and represent the major contribution for the high accumulation of pollutants in sediments, namely metals (Pereira et al., 1997). One of the metals known to be present at higher concentrations than background levels is mercury (Lucas et al., 1986; Hall et al., 1987; Pereira, 1997; Pereira et al., 1998). The main anthro-

\footnotetext{
* Corresponding author. Tel.: +351 234370 737; fax: +351 234370084. E-mail address: pmartins@dq.ua.pt (P. Pato).
}

pogenic source of mercury to the lagoon is the effluent from the chlor-alkali plant that discharged into a channel which drains to a basin where fisheries and recreation activities takes place. During the last decade, the industry changed the production process leading to a considerable decrease of mercury discharges (Pereira, 1997). Nevertheless, mercury discharged in past years has been deposited progressively in sediments (Pereira et al., 1998). This work discusses the extent of sediment mercury retention in the most contaminated sites in the lagoon, and its exportation to the water column as well as transfer to biogenic suspended particles and to sea bass (Dicentrarchus labrax). Therefore, the main question, with important environmental management implications, was to assess if mercury is effectively retained in the sediments or is progressively released to the water column in considerable amounts.

In April 1997, water samples were collected from sampling stations in the most contaminated area of the lagoon (Laranjo Basin, Fig. 1), both in high tide and low tide conditions. Sediments cores $(\approx 60 \mathrm{~cm})$ were also taken from two stations (A and B) (Fig. 1). In June 1998 plankton samples ( $63 \mu \mathrm{m}$ net) were collected in high tide and low tide conditions in Laranjo Basin and Muranzel (Fig. 1). During 1997 and 1998, in several periods of the year, specimens of sea bass (D. labrax) were captured at four stations located in different areas of the lagoon: Laranjo Basin, Muranzel, Costa Nova and Ílhavo (Fig. 1).

Water samples were filtered with $0.45 \mu \mathrm{m}$ Millipore filters. The filtrate was then acidified with $\mathrm{HNO}_{3}$ (Merck, "mercury-free") to $\mathrm{pH}<2$ and stored at $4{ }^{\circ} \mathrm{C}$ until 


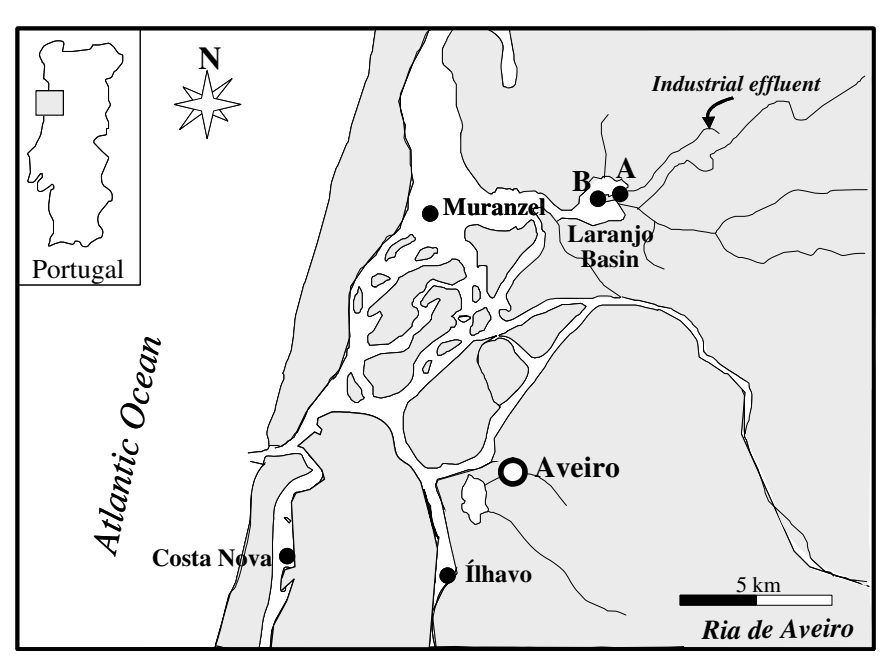

Fig. 1. Sampling stations in Ria de Aveiro.

analysis. Filters were also stored at $4{ }^{\circ} \mathrm{C}$ and before the mineralization process, were dried at $60{ }^{\circ} \mathrm{C}$ overnight. The extraction of total mercury was performed according to the methodology described in Pereira (1997). Sediment cores at each sampling station were collected with polyvinyl chloride tubes $(7 \mathrm{~cm}$ internal diameter and $1 \mathrm{~m}$ long). After collection of the upper $5 \mathrm{~mm}$, the remaining sediments core were sliced in $5 \mathrm{~cm}$ layers, the operation carried out under nitrogen atmosphere to prevent oxidation of anaerobic layers (Wallmann et al., 1996). Portions of the sediment samples were oven dried overnight at $60^{\circ} \mathrm{C}$, disaggregated, homogenised, manually sieved and the fraction $<1 \mathrm{~mm}$ separated. Determination of total mercury in sediments was accomplished by the same procedure used for suspended particulate matter (Pereira, 1997). A portion of sediment was preserved in nitrogen atmosphere until extraction of interstitial waters. To perform this extraction, sediments were centrifuged at $6000 \mathrm{rpm}$ for $20 \mathrm{~min}$ (B. Braun, model Sigma 4-10), and the liquid fraction was separated by decantation followed by filtration through $0.45 \mu \mathrm{m}$ Millipore filters. Filtrates were acidified to $\mathrm{pH}<2$ with concentrated $\mathrm{HNO}_{3}$ (Merck, "mercury-free") and stored at $4{ }^{\circ} \mathrm{C}$ until analysis of reactive mercury. All interstitial waters procedures were carried out under nitrogen atmosphere. Another portion of wet sediments was stored under a nitrogen atmosphere for determination of acid-volatile sulfide (AVS) by linear sweep voltammetry, as described by Casas and Crecelius (1994). The sea bass specimens, of $\approx 20 \mathrm{~cm}$ length, were dissected and the muscle tissue separated. This biological material was then weighed, freeze-dried and weighed again (dry weight $(\mathrm{dw}) /$ wet weight (ww) ratio). Mineralization of samples was performed according to Sadiq et al. (1991).

Determinations of dissolved reactive mercury concentrations (the fraction that can be reduced by stannous chloride at $\mathrm{pH}<2$ ) were carried out by cold-vapour atomic fluorescence spectroscopy (CV-AFS; PSA model Merlin 10.023 equipped with a detector PSA model 10.003, with tin chloride as reducing agent $(2 \%$ in $10 \% \mathrm{HCl}))$. Detection limits ranged between 0.4 and $1.5 \mathrm{ng} \mathrm{L}^{-1}$. The instrument was calibrated with at least five acidified standards (from 2 to $50 \mathrm{ng} \mathrm{L}^{-1}$ ). A standard solution of $20 \mathrm{ng} \mathrm{L}^{-1}$ was analyzed every three samples to check for instrument drift. Procedure blanks were always run with samples and its contribution corrected. Solutions from total mercury digestions were analysed by cold-vapour atomic absorption spectroscopy with pre-concentration in a gold trap (CV-AAS; Perkin-Elmer Model 3030B coupled with a MHS-20 Perkin-Elmer hydride system, with tin chloride as reducing agent).

Dissolved reactive mercury levels in Laranjo Basin water column, at low and high tide, ranged between 7 and $84 \mathrm{ng} \mathrm{L}^{-1}$. Mercury concentrations associated with suspended particulate matter at low tide ranged between 3.5 and $26 \mu \mathrm{g} \mathrm{g}^{-1}(\mathrm{dw})$, being higher than the levels observed at high tide, where values between 2.0 and $13 \mu \mathrm{g} \mathrm{g}^{-1}$ were found. The highest concentrations, in dissolved and particulate fractions were observed near the contamination source.

The vertical distribution of total mercury in sediments showed concentration maxima in both sampled stations (A and B), although with different intensity (Fig. 2). Maxima observed in vertical profiles of mercury in sediment solid fractions reflected the intensity of the discharges in the last decades, as was also shown in previous studies (Pereira et al., 1997, 1998). It was observed, in both stations, that for acid-volatile sulphides for all depths, the highest levels were found between 20 and $40 \mathrm{~cm}$ (vertical distribution shown as a dotted line in Fig. 3). Vertical profiles of mercury concentrations in sediment interstitial waters for both sampling stations are also given in Fig. 3 . At certain depths, mercury levels in inter- stitial waters increased, resulting in pronounced maxima. These maxima were found at similar depths in both sampling stations and were located, in general, in layers with higher AVS levels. Assuming that sulphides in sediments are in equilibrium with interstitial waters, the concentrations of hydrogen sulphides should also be higher in the same layers. Paquette and Helz (1995) showed that mercury sulphide (cinnabar)

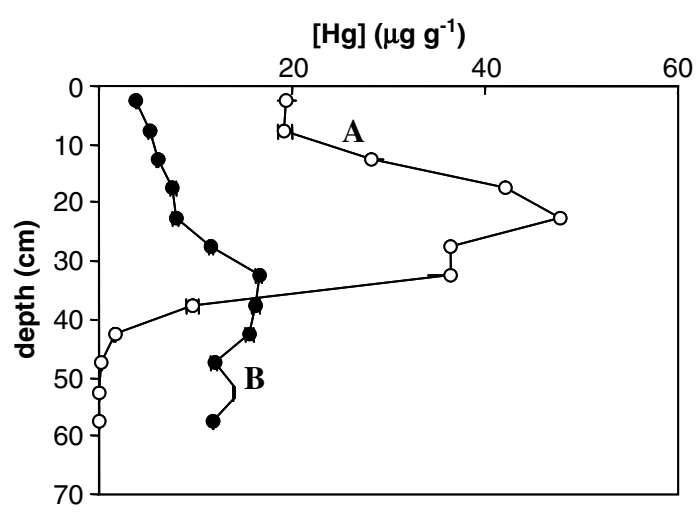

Fig. 2. Vertical distribution of total mercury concentrations $\left(\mu \mathrm{g} \mathrm{g}^{-1}, \mathrm{dw}\right)$ in sediments from stations $\mathrm{A}$ and $\mathrm{B}$. 

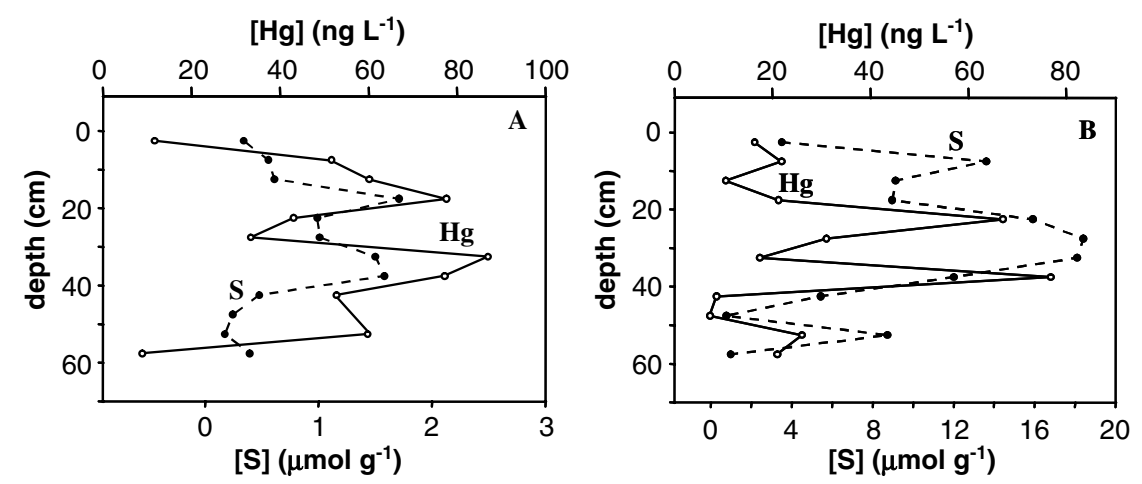

Fig. 3. Vertical distribution of mercury concentrations $\left(\mathrm{ng} \mathrm{L}^{-1}\right)$ in interstitial waters and AVS levels $\left(\mu \mathrm{mol} \mathrm{g}^{-1}\right.$, dw) in sediments of sampling stations A and $\mathrm{B}$.

dissolves in sulphidric conditions in the $\mathrm{pH}$ range usually found in natural waters. Thus, the relationship between mercury and sulphur levels in sediments interstitial waters of Laranjo Basin might be an indication of the presence of more soluble mercury species, namely, mercury polysulphides as suggested by Muhaya et al. (1997).

Interstitial water mercury concentrations for the sediment upper $5 \mathrm{~mm}$ were found to be similar (in the range of $100 \mathrm{ng} \mathrm{L}^{-1}$ ) at both sampling stations and these levels were one order of magnitude higher than those observed in the water column. The higher mercury concentrations in sediment interstitial waters clearly indicates an export of this element from sediment to water column by molecular diffusion (Berner, 1980). Given the differences found in dissolved mercury levels in the water column between low tide and high tide and between stations A and B, the diffusive fluxes were calculated (Berner, 1980) in the four cases (Table 1). Results showed that diffusive fluxes are similar in both sampling points. The results shown in Table 1 lead to the conclusion that the contribution of sediment is poor when compared with mercury concentrations observed in the water column, meaning that levels present in water result mainly from industrial discharges and tidal range oscillation.

Mercury levels in suspended particles collected with a plankton net $(63 \mu \mathrm{m})$ in Laranjo basin and Muranzel, at low tide and high tide, are shown in Table 2. It was observed that a decrease in mercury levels occurred with distance from the channel where the anthropogenic source discharges. Mercury concentrations in samples collected inside the Laranjo Basin were 1-2 orders of magnitude higher than those found in material sampled in Muranzel.
Table 2

Mercury concentrations ( $\mu \mathrm{g} \mathrm{g}^{-1}$, ww) in samples collected with a plankton net $(63 \mu \mathrm{m})$ at low tide and high tide in Laranjo Basin and Muranzel

\begin{tabular}{lll}
\hline Sampling station & Tide & $\mathrm{Hg}\left(\mu \mathrm{g} \mathrm{g}^{-1}\right)$ \\
\hline Laranjo Basin & Low tide & 0.81 \\
\multirow{3}{*}{ Muranzel } & High tide & 0.25 \\
& Low tide & 0.024 \\
& High tide & 0.016 \\
\hline
\end{tabular}

Concentrations of mercury in samples collected at low tide were higher than concentrations observed at high tide. Results of mercury concentrations in samples collected with plankton nets indicate that $\mathrm{Hg}$ is incorporated in the biogenic particles found in Laranjo Basin (by observation with a magnifying glass, it was evident that particles retained in the net were mainly of biogenic origin).

Mercury concentrations in muscles of sea bass captured at the four sampling stations are shown in Fig. 4. A large range of mercury concentrations was observed, (between 1.3 and $0.084 \mu \mathrm{g} \mathrm{g}^{-1}$, ww). Higher concentrations levels were found in Laranjo Basin (mean of $1.05 \mu \mathrm{g} \mathrm{g}^{-1}$, ww), decreasing to less than a half in Muranzel (mean of $0.45 \mu \mathrm{g} \mathrm{g}^{-1}$, ww). Laranjo Basin was the only station with levels exceeding the maximum total mercury level stipulated by the European Commission Decision for Sea Bass $\left(1.0 \mu \mathrm{g} \mathrm{g}^{-1}\right.$, ww). In the other two stations levels in individuals were even lower, with concentrations one order of magnitude below the values observed in Laranjo Basin (mean of 0.15 and $0.11\left(\mu \mathrm{g} \mathrm{g}^{-1}\right.$, ww) in Ílhavo and Costa Nova, respectively).

Table 1

Dissolved mercury concentrations $\left(\mathrm{ng} \mathrm{L}^{-1}\right)$ in interstitial waters and the water column in April 1997, and diffusive fluxes (ng $\mathrm{cm}^{-2} \mathrm{~h}^{-1}$ ) according to Flick's first law

\begin{tabular}{|c|c|c|c|c|c|}
\hline \multirow[t]{2}{*}{ Sampling station } & \multirow[t]{2}{*}{ Interstitial waters $\left(\mathrm{ng} \mathrm{L}^{-1}\right)$} & \multicolumn{2}{|c|}{ Water column $\left(\mathrm{ng} \mathrm{L}^{-1}\right)$} & \multicolumn{2}{|c|}{ Diffusive flux $\left(\mathrm{ng} \mathrm{cm}^{-2} \mathrm{~h}^{-1}\right)$} \\
\hline & & High tide & Low tide & High tide & Low tide \\
\hline A & 94 & 12 & 53 & $2.2 \times 10^{-3}$ & $1.0 \times 10^{-3}$ \\
\hline B & 117 & 10 & 25 & $3.5 \times 10^{-3}$ & $3.0 \times 10^{-3}$ \\
\hline
\end{tabular}




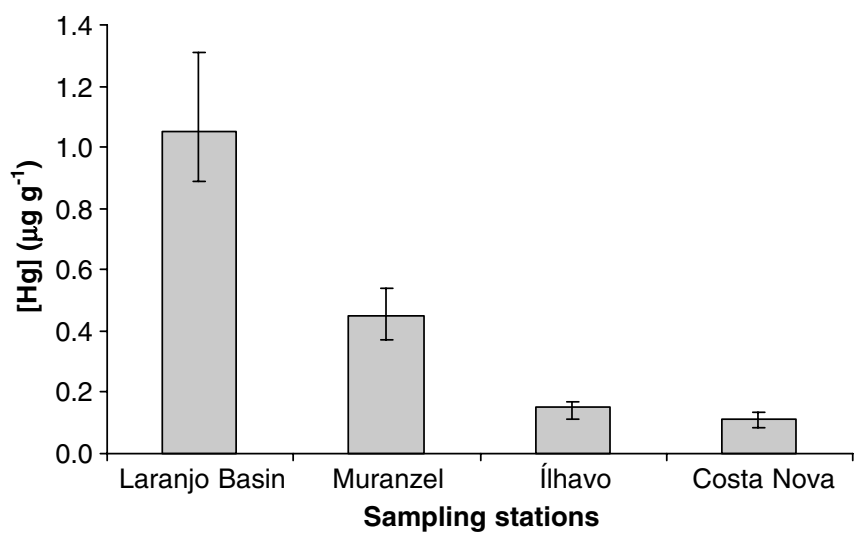

Fig. 4. Mercury concentrations ( $\mu \mathrm{gg}^{-1}$, ww) in muscles of sea bass captured in Laranjo Basin $(n=7)$, Muranzel $(n=5)$, Costa Nova $(n=12)$ and Ílhavo $(n=11)$. Error bars represent maxima and minima individual results.

In conclusion, the results indicate that mercury concentrations in the water column are mostly related with distance to the industrial source, and with tidal dynamics. Deeper sediments showed elevated mercury concentrations when compared with surface layers, reflecting the existence of higher discharges of mercury in the past. Vertical profiles of mercury in interstitial waters indicate remobilization of mercury in reducing environments. Nevertheless, estimated diffusive fluxes through the sediment-water interface indicate that the exported quantity is small and fails to justify the levels present in the water column. The variation of mercury concentrations in water and in the suspended particles (particles collected with $63 \mu \mathrm{m}$ net and retained in $0.45 \mu \mathrm{m}$ Millipore filters) clearly indicates the importance of present-day industrial discharges to the local contamination. The exportation of mercury from the most contaminated areas to the rest of the lagoon appears to be due to transport of resuspended sediments and contaminated plankton. Mercury concentrations in sea bass captured in areas with different degrees of contamination show that mercury is readily accumulated by organisms that spend time in the area most affected by the industrial discharge of the metal.

\section{References}

Arakel, A.V., 1995. Towards developing sediment quality assessment guidelines for aquatic systems: an Australian perspective. Aust. J. Earth Sci. 42, 335-369.
Becher, D.S., Bigham, G.N., 1995. Distribution of mercury in the aquatic food web of Onondaga Lake, New York. Water Air Soil Pollut. 80, 563-571.

Berner, R.A., 1980. Early diagenesis - a theoretical approach. Princeton University Press, New Jersey, USA, 241 pp.

Casas, A.M., Crecelius, E.A., 1994. Relationship between acid volatile sulfide and the toxicity of zinc, lead and copper in marine sediments. Environ. Toxicol. Chem. 13 (3), 529-536.

Chapman, P., 1997. Is Bioaccumulation Useful for Predicting Impacts. Marine Pollut. Bull. 34 (5), 282-283.

Driscoll, C.T., Blette, V., Yan, C., Schofield, C.L., Munson, R., Holsapple, J., 1995. The role of dissolved organic carbon in the chemistry and bioavailability of mercury in remote Adirondack Lakes. Water Air Soil Pollut. 80, 499-508.

Hall, A., 1982. Water Quality Problems in Ria de Aveiro. In: Actual Problems of Oceanography in Portugal. Ed. Junta Nacional de Investigação Científica e Tecnológica and Nato Marine Sciences Panel, Lisboa, 159-169.

Hall, A., Duarte, A.C., Caldeira, M.T.C., Lucas, M.F.B., 1987. Sources and sinks of mercury in the coastal lagoon of Aveiro, Portugal. Sci. Total Environ. 64, 75-87.

Lawson, N.M., Mason, R.P., 1998. Accumulation of mercury in estuarine food chains. Biogeochemistry 40, 235-247.

Lee, C.-L., Fang, M.-D., Hsieh, M.-T., 1998. Characterization and distribution of metals in surficial sediments in Southwestern Taiwan. Marine Pollut. Bull. 36 (6), 464-471.

Lucas, M.F., Caldeira, M.T., Hall, A., Duarte, A.C., Lima, C., 1986. Distribution of mercury in the sediments and fishes of the Lagoon of Aveiro, Portugal. Water Sci. Technol. 18, 141-148.

May, T.W., Wiedmeyer, R.H., Brumbaugh, W.G., Schmitt, C.J., 1997. The determination of metals in sediment pore waters and in $1 \mathrm{~N} \mathrm{HCl}$ extracted sediments by ICP-MS. At. Spectrosc. 18 (5), 133-139.

Muhaya, B.B., Leermakers, M., Baeyens, W., 1997. Total mercury and methylmercury in sediments and in the polychaete Nereis Diversicolor at groot buitenschoor (Scheldt Estuary, Belgium). Water Air Soil Pollut. 94, 109-123.

Paquette, K., Helz, G., 1995. Solubility of cinnabar (red HgS) and implications for mercury speciation in sulfidic waters. Water Air Soil Pollut. 80, 1053-1056.

Pereira, M.E., Duarte, A.C., Millward, G.E., Abreu, S.N., Reis, M.C., 1997. Distribution of mercury and other heavy metals in the Ria de Aveiro. Quím. Anal. (Barcelona) 16 (Suppl. 1), S31-S35.

Pereira, M.E., Duarte, A.C., Millward, G., Abreu, S.N., Vale, C., 1998. An estimation of industrial mercury stored in sediments of a confined area of the Lagoon of Aveiro (Portugal). Water Sci. Technol. 37, 125130.

Pereira, M.E., 1997. Distribuição, reactividade e transporte do mercúrio na Ria de Aveiro. Ph.D. Thesis, Departamento de Química, Universidade de Aveiro, 284 pp.

Sadiq, M., Zaidi, T.H., Al-Mohana, H., 1991. Sample weight and digestion temperature as critical factors in mercury determination in fish. Bull. Environ. Contam. Toxicol. 47, 335-341.

Wallmann, K., Petersen, W., Reiners, C., Gramm, H., 1996. Trace element diagenesis in polluted sediments of the River Elbe Estuary. In: Calmano, W., Forstner, U. (Eds.), Sediments and Toxic Substances. Springer-Verlag, Berlin, Germany, pp. 197-213. 